\title{
Development artificial dental filling (PMMA) for antibacterial and wear resistance enhanced by bioceramic system $\mathrm{CaTiO}_{3}$
}

Received : 7/12/2017

\author{
Fadhil K. Farhan ${ }^{1}$ Zainab Al-Ramadhan ${ }^{2}$ \\ ${ }^{1}$ Ministry of Science and Technology, Baghdad, Iraq \\ ${ }^{2}$ Al-Mustansiriyah University, College of Education, Department of Physics, \\ P.O.Box:46219, Baghdad, Iraq \\ Ali Hadi Hassan Al-Batat ${ }^{2}$
}

Accepted : 18/1/2018

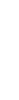

email: dr.fadhilkareem@gmail.com

email: zainabphysics@yahoo.com

email: drr.alihadi@uomustansiriyah.edu.iq

\begin{abstract}
:
In this paper, bioactive ceramics of calcium oxides prepared from egg shells and nano-titanium dioxide were used in a 1: 1 ratio and were mixed with a polymeric bonding material suitable for medical applications. Dry mixing and homogenous mixing were used. Ultrasonic technology was then used to prepare the nanoparticles that were then formed in standard dimensions for the purpose of conducting the required tests. The screw technique was used on the disk to calculate the rate of wear and tear, weight and volume, as well as the wear and tear coefficient. The concrete hardness scale was used to calculate the scratch resistance of the surface. The results of the various types of wear and tear index were significantly improved by the successive additions of ceramic material (calcium tetanite) as well as by increasing the scratch resistance of the prepared models obtained from the hardness scale. Synthetic tests (electronic scanning microscopy and x-ray diffraction) were used to interpret the results as well as to examine the material prepared against the bacteria.
\end{abstract}

Keywords: Bioceramic, Calcium Oxide, Titanium Dioxide, pin - on -Disc, Nanoparticles

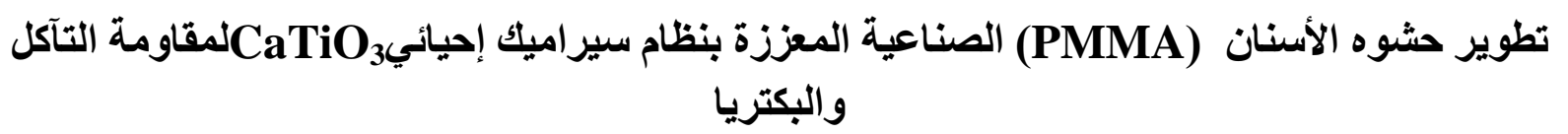

الخلاصة:

في هذا البحث تم تحضير سير اميك فعال إحيائيا من اوكسيد الكالسيوم المحضر من قنتور البيض وثنائي اوكسيد

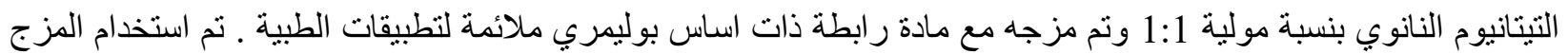

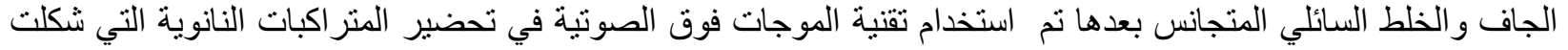

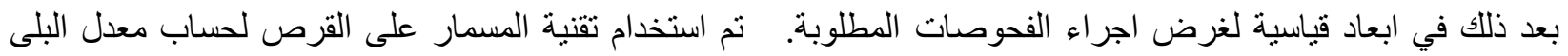

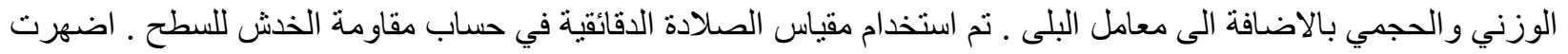

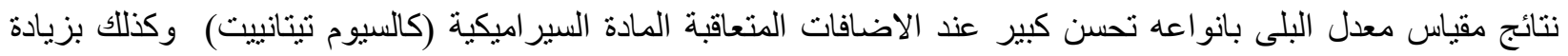

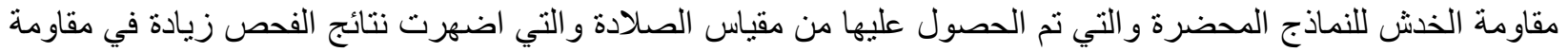




\section{AL-Qadisiyah Journal of pure Science $\quad$ Vol.23 No.1 Year 2018}

$$
\begin{aligned}
& \text { الخدش بزيادة المادة المضافة. تم الاستعانة في الفحوصات التركيبية (المجهر الالكتروني الماسح وحيود الاشهة السينية) في }
\end{aligned}
$$

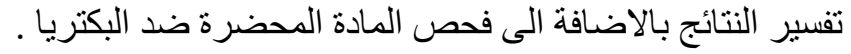

$$
\begin{aligned}
& \text { الكلمات المفتاحية: سير اميك إحيائي ، وكسيد الكالسيوم ، ثنائي وكسيد التيتانيوم ، مسمار على قرص ، المتر اكبات النانوية }
\end{aligned}
$$

\section{Introduction:}

Acrylic polymers were utilized as denture base materials since 1937 [1].They were so well received by dental professionals that, by 1946 , approximately $98 \%$ of all denture bases were base don PMMA. The cured polymer should be stiff enough to hold the teeth in occlusion during mastication and to minimize uneven loading of mucus under the denture. The denture material should not creep under masticator loads for long-term use if good occlusion is to be maintained and potential irritant effects are kept at minimum [2]. Such material should also have sufficient strength and resilience to withstand normal masticator forces; withstanding sudden shock caused by impact forces is an important property. The material should not deteriorate in the aqueous environment of the mouth, and craze formation caused by solvents presenting food, drinks, or medicaments should be absent or minimal [3].Polymers are important in dentistry because their distinctive properties allow a range of clinical applications, which are impossible with the use of other types of materials. The most widely used impression materials (alginates, polyether, poly-sulfides, and silicones) are polymers. Further applications include denture bases, artificial teeth, cements, dies, provisional crowns, endodontic fillings, tissue conditioners, and pit and fissure sealants. Poly(methyl methacrylate) (PMMA) is extensively used as a denture base material [4].However this material is not ideal in every aspect, particularly in satisfying the mechanical requirements of prosthesis. Fracture of acrylic resin denture base occurs frequently because of fatigue and chemical degradation of base material [5]. Bioactive ceramics have become one of the major fields in medicine over the last three decades. One remarkable success of bioactive ceramics is the clinical use of sintered hydroxyapatite (HA) for implants due to its bioactivity and conductivity [6]. Calcium titanate $\left(\mathrm{CaTiO}_{3}\right)$ is a ceramic material with a perovskite structure. This compound does not show anisotropy, and its structure is cubic above $1307{ }^{\circ} \mathrm{C}$, tetragonal between 1107 and $1227{ }^{\circ} \mathrm{C}$ and orthorhombic below $1107{ }^{\circ} \mathrm{C}$ [7]. The cubic perovskite structure can be obtained at room temperature when doped with action receptors. $\mathrm{CaTiO}_{3}$ shows distinct structural, electrical and optical properties and, therefore, is of great scientific and technological interest [8]. Titanium oxide $\left(\mathrm{TiO}_{2}\right)$ has various applications in the food, cosmetics, aero spatial and biomedical areas because it contains a bio-inert phase and can be osteo-integratable to the adjacent tissue[9]. $\mathrm{TiO}_{2}$ in nanoparticle form can reach good levels of bioactivity, promoting bone tissue proliferation on nanoparticles and tissue attachment to biomaterial interface[10]. The results indicated that a very important group of materials is based on $\mathrm{CaO}-\mathrm{TiO}_{2}$ and $\mathrm{CaO}-\mathrm{Al}_{2} \mathrm{O}_{3}-$ $\mathrm{TiO}_{2}$ systems that might be used as novel bioactive materials for bone regeneration [11].M. Kharaziha and M.H. Fathi, studded Synthesis and characterization of bioactive founded forsterite and provskite ceramic is a new bio-ceramic with good biocompatibility[12].Nelson H. A and Sarah A. studded synthesis and characterization of 
$\mathrm{HA} / \mathrm{TiO}_{2} \mathrm{n}$ Nano-composites for bone tissue regeneration, the $\mathrm{HA}$ (hydroxyapatite) used as bone matrix in this work was produced by the biomaterials [13]. In another work Tabata et al [14] studied the wear rate of eight commercially available artificial teeth samples.Gravimetric method was used to measure wear rate of these materials and the weight were measured before and after testing by analytical balance. The difference in weight was related to wear rate of each artificial toothache et al [15] studied the effect of $\mathrm{SiO}_{2}$ nano particles on hardness and wear ability of artificial teeth. For this purpose they dispersed $\mathrm{SiO}_{2}$ nano particles in MMA monomer and compared this composite resin with conventionally heat-cured resin. Results showed that nano- composite had better hardness and wear resistance properties than conventional heat cured resin based materials. In this work wear resistance properties of filling artificial teeth developed from wear resistant polymeric composites, containing calcium titanate has been studied and compared to commercial filling

\section{Experimental and Materials :}

Preparation of bioceramic:

The starting materials for the preparation of calcium titanate, $\mathrm{CaTiO}_{3}$ were $\mathrm{CaCO}_{3}$ and $\mathrm{TiO}_{2}$ (Rutile type) of purity > $99.99 \%$, grain size $44 \mathrm{~nm}$. A reactive form of $\mathrm{CaO}$, obtained from eggshells after clinking and crushing to semi-powders and then burned in reaction furnace at $450{ }^{\circ} \mathrm{C}, 700^{\circ} \mathrm{C}, 900{ }^{0} \mathrm{C}$ was obtained on powder $\mathrm{CaCO}_{3}$ and was decomposition in electrical furnace at $1100{ }^{\circ} \mathrm{C}$.

\section{Preparation of Teeth Filling:}

In this work, the toothpaste was prepared by mixing certain percentages of the prepared ceramic $\mathrm{CaTiO}_{3}$ powder and mixing it with acrylic (PMMA) powder by using the grinding balls for two hours to obtain the best homogeneity between the powders and then using the chloroform solvent for the mixing process and forming the paste using the artificial teeth. The wear rate of the test samples was assessed from the weights of the worn out material during the wear experiments. Wear experiments were conducted under the constant applied load of 30 Newton for various sliding distance in the presence of artificial saliva. The weight loss of the test tooth was recorded in all the wear experiments and from which the wear rate was estimated by using the following equations [16].

$\mathrm{W}_{\mathrm{r}}=\Delta \mathrm{m} / \mathrm{L}$

$\mathrm{W}_{\mathrm{v}}=\Delta \mathrm{m} / \mathrm{L} \rho \mathrm{F}$

Where: $\Delta \mathrm{m}=$ weight loss $(\%), \mathrm{W}_{\mathrm{r}}=$ wear rate $(\mathrm{g} / \mathrm{cm}), \mathrm{W}_{\mathrm{v}}=$ wear volume $\left(\mathrm{mm}^{3} / \mathrm{Nm}\right), \mathrm{L}=$ Sliding distance $(\mathrm{m}), \rho=$ Density and $\mathrm{F}-$ Force $(\mathrm{N})$.

$\mathrm{W}_{\text {Coeff }}=\boldsymbol{W}_{\mathrm{v}} \cdot \boldsymbol{H}_{V} / L F$

Where: Wcoeff. - wear of coefficient and $\mathrm{H}_{\mathrm{V}}-$ micro hardiness in $\mathrm{MPa}$

The calcium Oxide was handled carefully to prevent the adsorption of $\mathrm{CO}_{2}$ and $\mathrm{H}_{2} \mathrm{O}$ from ambient air. The rutile form of $\mathrm{TiO}_{2}$ was dried at $500{ }^{0} \mathrm{C}$ before use. Calcium titanate $\mathrm{CaTiO}_{3}$ were prepared by active mechanical mixtures method of $1: \mathrm{CaO}$ and $1: \mathrm{TiO}_{2}$ in the appropriate molar ratio $1: 1$ for milling $12 \mathrm{~h}$. Prepared material from blending process was reaction at temperature $1250{ }^{\circ} \mathrm{C}$.

technique of ultersonic for half an hour. The samples were then molded into standard size molds for the purpose of conducting the required tests. The weights used are 5\%,7.5\%,10\% and $15 \%$ of the bio-ceramic powder. Five different artificial teeth filling samples were prepared and their wear 
resistances were measured. For practical applications, the artificial teeth filling Require high wear resistance in saliva. Artificial saliva was prepared using different salts following the procedures described in [17] and its composition has been detailed in Table 1 .

\begin{tabular}{|c|c|}
\hline Salt & Concentration (g.dm-3) \\
\hline NaCl & 0.4 \\
\hline KCl & 0.4 \\
\hline CaCl2.2H2O & 0.795 \\
\hline NaH2PO4.2H2O & 0.78 \\
\hline Na2S.9H2O & 0.005 \\
\hline (NH4)2CO3 & 1 \\
\hline
\end{tabular}

Table(1): Chemical composition of artificial saliva

\section{$\underline{\text { Results and Discussion: }}$}

The test of the scanning electron microscopy(SEM) shown figure(1) of the bioceramic powder $\mathrm{CaTiO}_{3}$ at temperature sintering $\quad 1250{ }^{0} \mathrm{C}$ indicates a homogeneous form of granular size so that the materials entering from each other cannot be distinguished if they are single and this is evident when 10KX.Thefigurer (2) shown X-ray analysis of the bioceramic powder prepared at temperature $1250{ }^{0} \mathrm{C}$ with the Crystalline Cube System peroviskite structures. The grain size average of papered powder it is $(38 \mathrm{~nm})$ measurement by Schere's equation. Figure (3) shows the XRF pattern of the bioceramic powder after sintering and pressing. The dominant XRF peaks belong to Calcium Oxide $\mathrm{CaO}$, dioxide titanium $\mathrm{TiO}_{2}$, so the high and low of intensity this back to percentage of content powders .From figure showed results match between experimental and test. This may have caused the accuracy of mixing and pure materials used.

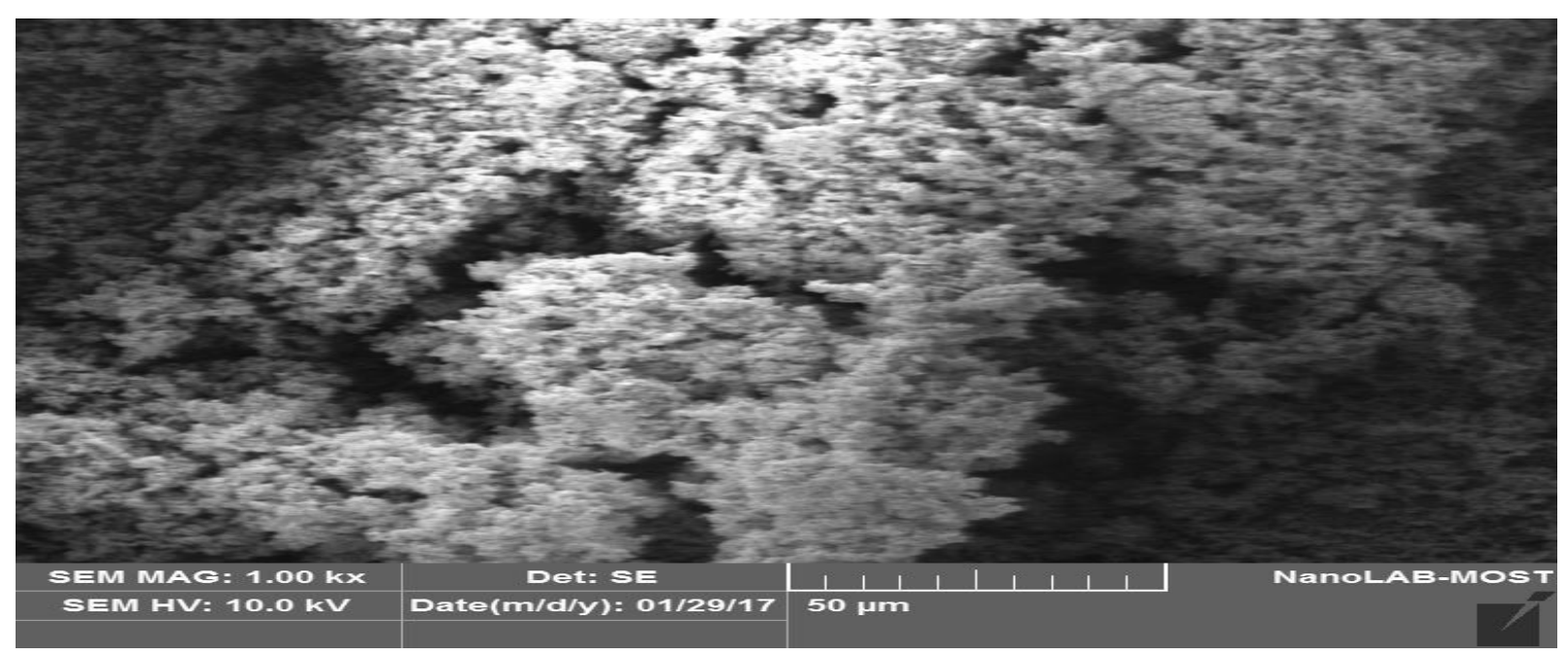


Figure(1): Image SEM test of $\mathrm{CaTiO}_{3}$ bioceramic Powder at $1250{ }^{\circ} \mathrm{C}$

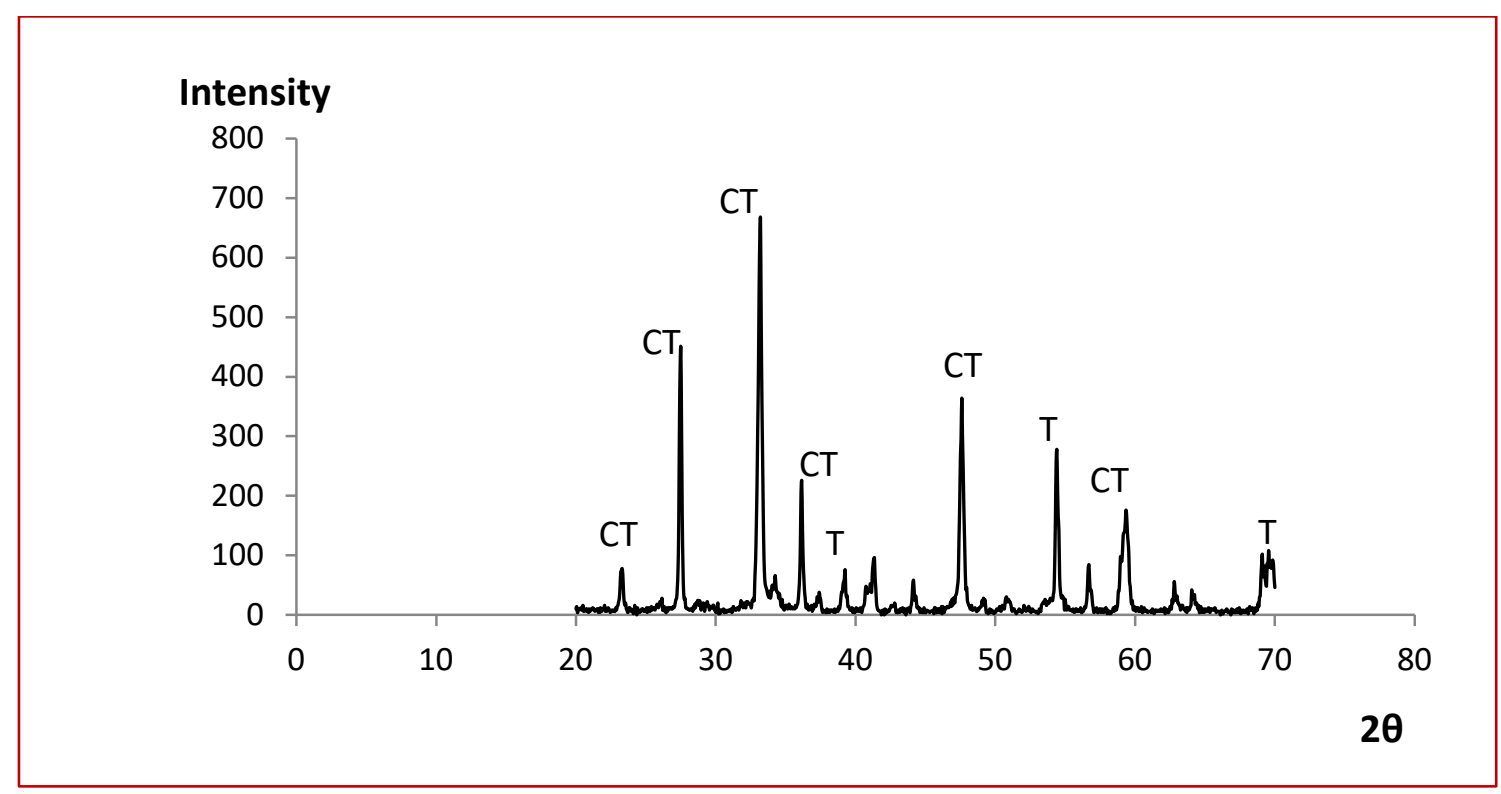

Figure( 2):XRD patterns of bioceramic powder $\mathrm{CaTiO}_{3}$

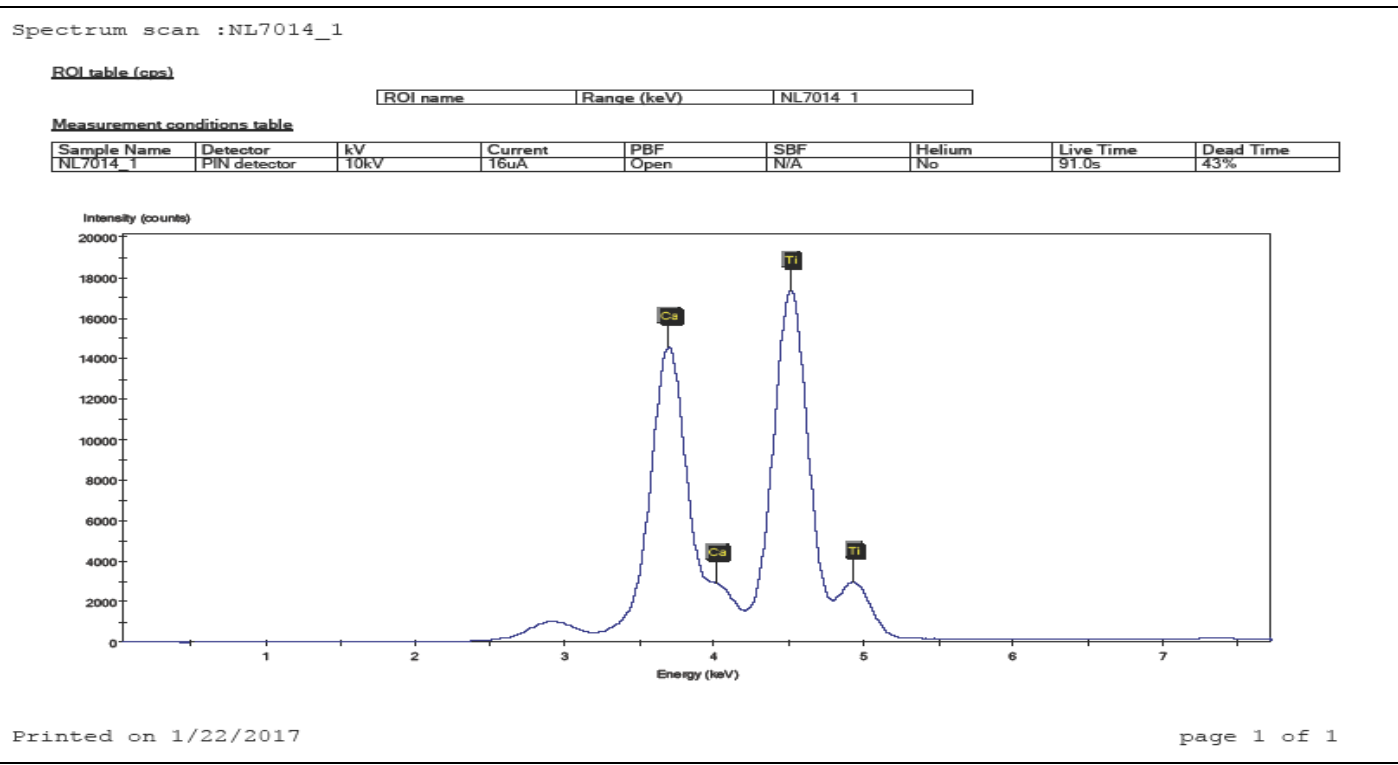

Figure(3):XRF - analysis of $\mathrm{CaTiO}_{3}$ Constrictions 
The results of the test of the rate of wear of various types (weight, volume, and wear 3)to calculator wear rate types and this is all summarized in Table 2 and figures $(3,4,5)$.The

\begin{tabular}{|c|c|c|c|c|c|c|c|}
\hline \multirow[t]{2}{*}{ NO. } & \multirow[t]{2}{*}{$\Delta \mathrm{m}$} & \multirow{2}{*}{$\begin{array}{r}\mathbf{W}_{\mathbf{r}} \\
\times 10^{-6}\end{array}$} & \multirow{2}{*}{$\begin{array}{r}\mathbf{W}_{\mathbf{v}} \\
\times 10^{-6}\end{array}$} & \multirow{2}{*}{$\begin{array}{c}\mathbf{H}_{\mathbf{v}} \\
\mathbf{M P a}\end{array}$} & \multicolumn{2}{|c|}{$\mathbf{W}_{\text {coeff. }}$} & \multirow{2}{*}{$\begin{array}{c}\rho \\
\mathrm{Kg} / \mathrm{m}^{3}\end{array}$} \\
\hline & & & & & $\begin{array}{c}\text { Immersion } \\
\text { In saliva }\end{array}$ & In air & \\
\hline $0 \%$ & 0.130 & 0.3 & 13.10 & 19.8 & 0.003 & 0.028 & 1150 \\
\hline $5 \%$ & 0.0071 & 0.016 & 6.32 & 23.9 & 0.002 & 0.0019 & 1266 \\
\hline $7.5 \%$ & 0.0031 & 0.007 & 0.26 & 35.7 & 0.0001 & 0.00009 & 1345 \\
\hline $10 \%$ & 0.0011 & 0.003 & 0.11 & 48.5 & 0.00006 & 0.000057 & 1405 \\
\hline $15 \%$ & 0.0004 & 0.0009 & 0.03 & 65.7 & 0.00002 & 0.000016 & 1536 \\
\hline
\end{tabular}

coefficient) showed significant improvement and high resistance to corrosion with and without industrial saliva by testthe samples using pin-on - disctechnique. Was used equations (1,2 and
The improved rate of wear resistance enhanced by the ceramic system is due to three important reasons. First, the high hardness of this type of system because its molecules are in the form of a mixture of solid pipes of the titanium dioxide and the semi-spherical which belong to the calcium oxide shown figurer (4). The second reason is the homogeneous and regular distribution of ceramic powder into polymer's condition resulted in the distribution of stress and pressure evenly on the surface. The final reason is that the selection of the appropriate ratios for the enhanced material was so that the ratios of less $5 \%$ and higher than $15 \%$ were tested .The results obtained were not encouraging. When less than $5 \%$, there is no wear rate measurement at applied load $20 \mathrm{~N}$, and constant sliding distance equal $4396 \mathrm{~m}$ at all samples.

\section{Table(2): Experimental of wear rate before and after immersion.}

apparent effect of wear resistance compared to the base material. When the ratio is higher than $15 \%$, the difficulty of homogenous distribution and the occurrence of gaps in the samples is a failure that leads to the collapse of the filling in the future and its erosion in a short time this is agreement with [18]. The photographs shown in figurer (5) the results of the bacterial examination of the prepared fillings. We note from the circular images surrounding the fill that the amount of resistance to the bacteria is the larger the diameter of the circle, the shorter it indicates the efficiency of filling 


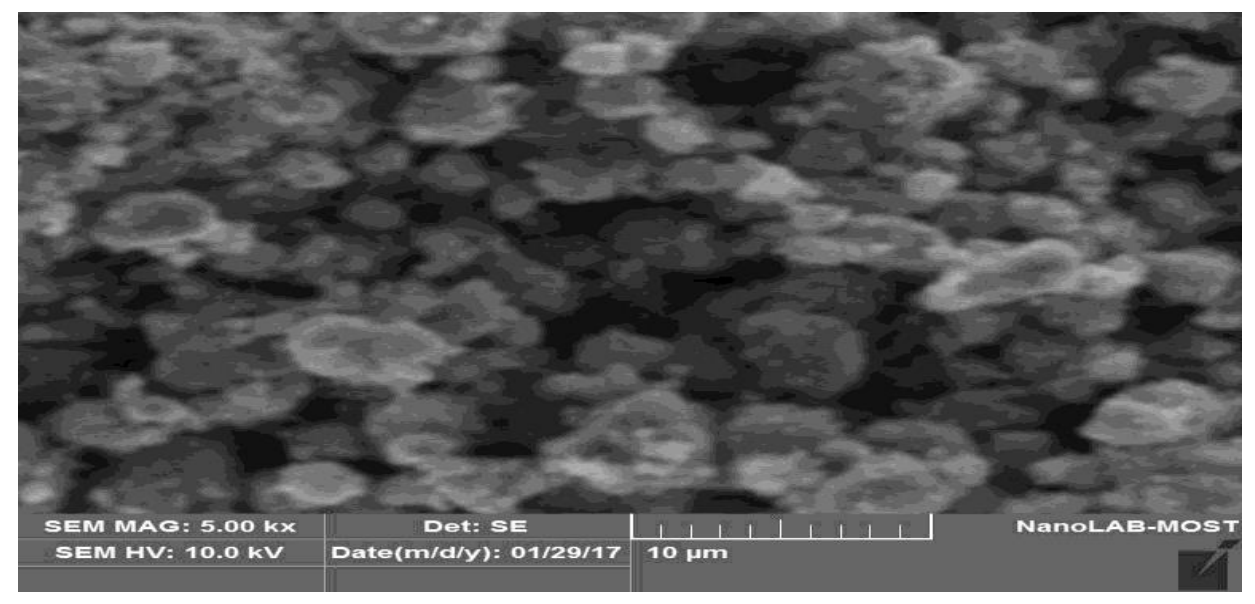

Figure(4):MorphologySEM pattern of PMMA/15\% $\mathrm{CaTiO}_{3}$
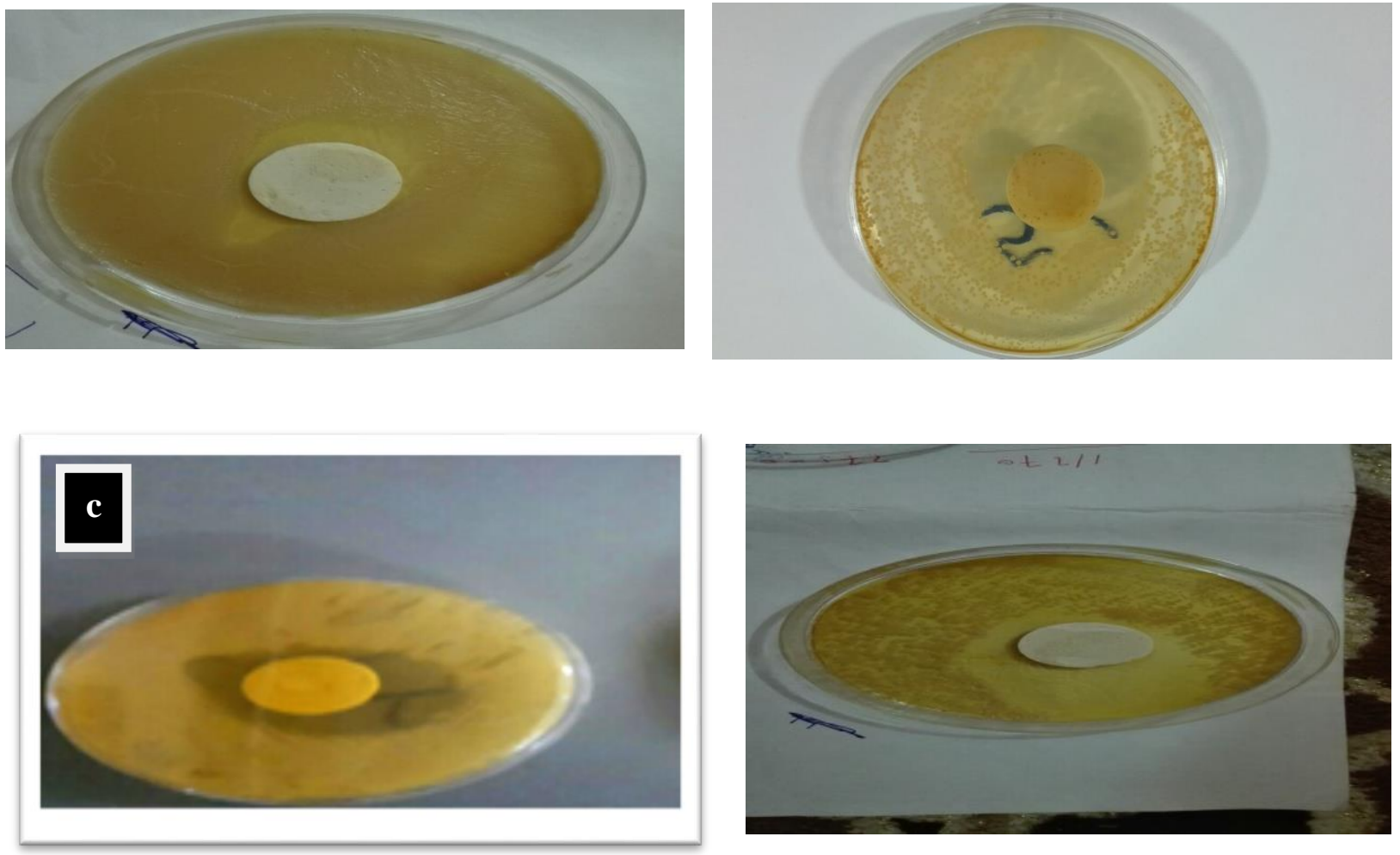

Figure(5): Images of artificial teeth filling results of antibacterial test.(a) PMMA

(b) $5 \% \mathrm{CaTiO}_{3}$. (c) $10 \% \mathrm{CaTiO}_{3}$ and (d) $15 \% \mathrm{CaTiO}_{3}$

\section{Conclusion}


In this research we can deduce

Bioceramic powderCaTiO $\mathrm{Co}_{3}$ is a suitable material for medical purposes and this is observed from the examination of antibacterial. The most effective weight ratio should not be less than $5 \%$ and not more

\section{References}

[1].M.V.Kumar,S. Bhagath, 2010, Historical interest of denture base materials'. of Dental Sciences, 1, No.1, pp.103-105

[2]. G. A. V. M. Geerts, J. Overturf, and T. G. Oberholzer,2008, The effect of different reinforcements on the fracture toughness of materials for interim restorations, J. of Prosthetic Dentistry, 99, No.6, pp.461-467

[3]. S. M. Lee, 1987, Advances in Biomaterials, Technomic, Lancaster Calif, USA,.

[4]. R. Tandon, S. Gupta, and S. K. Agarwal, 2010., "Denture base materi- als: from past to future," Indian Journal of Dental Sciences, vol. 2, no. 2, pp. 33-39,

[5]. D. C. Jagger, A. Harrison, and K. D. Jandt, 1999, "he reinforcement of dentures,"

JournalofOralRehabilitation,vol.26,no. 3,pp. 185-194,

[6].M.Kharaziha, M.H. Fathi, 2009, Synthesis and characterization of bioactive forsterite nano powder, Ceramics International 35 () 2449-2454 than $15 \%$ of the powder bio -ceramic and can be considered filling prepared with high resistance to wear of all types, and increases weight percentage of bioceramic powder increases Prepared filling efficiency.

[7]. A. Moulson, A. Herbert, 2003. Electroceramics: Materials, Properties, Applications, 2nd Ed. Wiley, New York,

[8]. B.J. Kennedy, C.J. Howard, B.C. 1999, Chakoumakos, "Phase transitions in perovskite at elevated temperatures- a powder neutron diffraction study", J. Phys- Condens. Mater., 6 () 1479-1485

[9]. T. Kolodiazhnyi, G. Annino, M. Spreitzer , T. Taniguchi, R. Freer, F. Azough, A. Panariello, W. Fitzpatrick, 2009, Development of $\mathrm{Al}_{2} \mathrm{O}_{3}-\mathrm{TiO}_{2}$ composite ceramics for high-power millimeter-wave applications". ActaMaterialia vol. 57,. P. 3402-3409.

[10]. D. Khang, J. Lu, C. Yao, K. M. Haberstroh, T. J. Webster. 2008, The role of nanometer and sub-micron surface features on vascular and bone cell adhesion on titanium" Biomaterials, vol. 29, 970-983.

[11]. Mirhadi S, Tavangarian F, Emadi R. 2012, Synthesis, characterization and formation mechanism of single-phase nanostructure bredigite powder. Mater SciEng C.;32(2):133-9.

[12]. M. Kharaziha, M.H. Fathi. 2009, Synthesis and characterization of bioactive forsterite nanopowder" Ceramics International 35 2449-2454

[13]. Nelson H. A. Camargo, Sarah A. de Lima, Gemelli. 2012, Synthesis and Characterization of Hydroxyapatite/ $/ \mathrm{TiO}_{2}$ Nanocomposites for Bone Tissue Regeneration" American Journal of Biomedical Engineering, 2(2): 41-47

[14] .L. F. Tabata, G. H. Filho, C. H. Goiato, 2005, Ci. Odontol. Bras. 8 , 6. 
[15] .W. Chen, Y. Li-Dan, Z. Yan-ping, U. X. Lian-Lai, 2006, Tianjin Med. Univ. $94,960$.

[16]. S. C. Ramesh, K. S. Seshardri, Wear 255 () 893.

[17]. W N. Muhammad1, S. Maitra Haq, M. Farooq,2003. Some studies on the wear resistance of artificial teeth in presence of amorphous $\mathrm{SiO}_{2}$ and $\mathrm{TiO}_{2}$ fillers, Cerâmica 57 (2011) 324-328

[18]. Arezou Sezavar, Seyed Mojtaba Zebarjad, and Seyed Sajjadi , 2015, [A Study on the Effect of Nano Alumina Particles on Fracture Behavior of PMMA], Technologies, 3, 94-102. 